\title{
NOT BOUND BUT COMMITTED: OPERATIONALISING THE GLOBAL COMPACT ON REFUGEES
}

\section{INTRODUCTION}

The United Nations General Assembly passed the annual omnibus resolution on the Office of the United Nations High Commissioner for Refugees (UNHCR) on 17 December 2018, including the Global Compact on Refugees (GCR). It was passed with 181 in favour, two against, the United States and Hungary, and three abstentions, Eritrea, Liberia and Libya (UNGA Press Release 2018). It represented the culmination of work over two years emanating from the September 2016 New York Declaration on Refugees and Migrants, including in Annex 1 the Comprehensive Refugee Response Framework (New York Declaration and CRRF). With 181 votes in favour, it is clear that the GCR was accepted by states across the world, those that produce refugees, refugee hosting countries of first destination, transit countries and countries that resettle, low- and middle-income countries as well as states in the global north.

With 68.5 million persons of concern to UNHCR, 23 million of whom are refugees, asylumseekers or returnees, a further 5.4 million Palestinians registered with the UN Relief and Works Agency, and where 85 per cent of refugees are in low- or middle-income countries, the international community is seeking to meet the various needs and fulfil obligations through the framework of the GCR (UNHCR Figures at a Glance). The GCR sets out to enhance refugee protection and to ensure fairer burden- and responsibility-sharing, but there are to be no additional duties imposed on states, in either direction: the refugee hosting states do not want any extension to the burden they already bear, while the richer states will not accept any specific obligations to ensure more predictable and fairer burden- and responsibility-sharing. Yet the compact is based on a 'commitment' to implement cooperation. The 1951 Convention relating to the Status of Refugees establishes obligations for the country of asylum with respect to refugees, but says little or nothing about the source state and support for those countries hosting enormous refugee populations (1951 Convention). The GCR seeks to fill that gap and therein lies the conundrum of no new obligations but with a commitment.

\section{RESEARCH QUESTIONS}

This article explores how the GCR puts in place a radical new approach to responding to forced displacement across borders that draws on international law generally and ideas that pre-date even the 1951 Convention. The most significant aspect of this analysis pertains to exploring the non-binding character of the GCR, but that can only be understood in relation to the means put in place for measuring its successful implementation by the international community as a whole (para 3, GCR). This discussion fits into the more general debate about the quality of international law qua law (Higgins 1994; Gilbert 2011; Crawford, 2012, 3-19; Allott 2016, 10.84-10.93; Koskenniemi 2018, 28-50). Even where there are binding treaty norms as between parties, there is not the same degree of structured enforcement mechanisms as one finds in national legal systems and a greater degree of reluctance to resort to judicial mechanisms rather than diplomacy. None of that questions the existence of international law, but it does make it easier to understand how an international instrument can eschew legal obligations, but still talk of commitments because that is in keeping with the practice of international relations. Nevertheless, the GCR adds a new layer to this discussion, for these commitments, which are not binding in international law, are to make burden- and responsibility-sharing more predictable, a primary quality of all true legal systems. 
SQUARING THE CIRCLE - NOT BOUND BUT COMMITTED(1)

The GCR provides in paragraph 4 that it is not legally binding. However, the paragraph goes on to provide:

Yet it represents the political will and ambition of the international community as a whole for strengthened cooperation and solidarity with refugees and affected host countries. It will be operationalized through voluntary contributions to achieve collective outcomes and progress towards its objectives, set out in para 7 below. These contributions will be determined by each State and relevant stakeholder, taking into account their national realities, capacities and levels of development, and respecting national policies and priorities.

Paragraph 5 then sets out that:

The global compact emanates from fundamental principles of humanity and international solidarity, and seeks to operationalize the principles of burden- and responsibility-sharing to better protect and assist refugees and support host countries and communities.

Better protection and assistance to refugees runs parallel with more equitable and predictable burden- and responsibility-sharing by the international community (GCR paras 1, 3, 7, 15, 48, and 101; UN Secretary-General 2017; ICVA 2018; ICRC BlogPost 2018). The conundrum of a non-binding document that is based on a commitment to providing 'concrete contributions ... based on the principle of burden- and responsibility-sharing' (GCR para 49) is the focus of this article, although there are several different elements to that 'focus': the character and nature of non-binding commitments in international law, indicators of success in the GCR's implementation, the humanitarian-development dichotomy, and solutions for refugees, host communities and the low- and middle-income countries that host 85 per cent of refugees.

\section{THE CHARACTER AND NATURE OF NON-BINDING COMMITMENTS IN INTERNATIONAL LAW}

International law, because of the nature of international society, is not as rigid as domestic law. For certain, international law can possess all the same binding characteristics as any domestic law or inter-party agreement, but there is scope for a greater range of arrangements affecting states, international organizations, non-state actors and even individuals - given the GCR applies to the "international community as a whole" and benefits refugees and hosting populations, one ought to expect a more flexible understanding of its international legal character (Cassese 1981; Sivakumaran 2006; Roberts \& Sivakumaran 2012; Murray 2014).

The binding quality of any document in international law may depend on the parties thereto, but also the nature and content of the document (Boyle \& Chinkin 2007). 'Soft law' is a term that is frequently used whenever a document lacks a traditional binding character, but, while not precise, even 'soft law' has understood characteristics and the GCR only satisfies some of those ( $c f$. Gammeltoft-Hansen 2019). Over time, the GCR may develop soft law, even customary characteristics, but, as it stands, it is not legally binding although it asserts it establishes commitments. One means by which to square this circle, between imposing no legally binding international obligations but yet establishing commitments to ensure burdenand responsibility-sharing, would be to recognise that international law is but one framework by which to hold states to account.

Political commitments

The GCR will give rise to political commitments even if it is not legally binding. Given that it is still rare for states to resort to judicial or quasi-judicial processes in order to hold other 
states accountable even where legally binding obligations exist,(2) governments nevertheless often regard politically binding obligations as just as authoritative in practice: they may not provide an in-built accountability and enforceability mechanism, but the commitment may be as strong for the state. And nor is it altruism, because states will recognise, for instance, that if support is given to the hosting state, there may be less onward movement by the refugee to states in the richer global north. In terms of non-legally binding commitments, the United Nations has established Agenda 2030 under the Sustainable Development Goals with no legal obligations on states to see that the goals are met (SDGs) and the Sendai Framework for Disaster Risk Reduction (Sendai), while the Organization for Security and Co-operation in Europe (OSCE) works mainly on consensus and has achieved much over several decades in practical terms with respect to minority rights and displacement (Gilbert 1997, 213-20). While the SDGs and Sendai include references to the voluntary character of those agreements rather than a non-binding character, both documents also refer to commitments and paragraph 4 GCR talks of voluntary contributions. While the precise nature may be different, the language is very similar.

However, the examples are not wholly apposite to the GCR. The OSCE was established to work by means of consensus and participating states operate on that expectation - the commitment without a legal obligation is part of the OSCE's very ethos, whereas the GCR has been established within the more traditional international framework of treaty obligations. Sendai only talks of establishing a review process (para 49), and although the SDGs establish targets for states in moving towards improvements in their own societies with no-one left behind, which is more akin to the GCR, only in 2030 will anyone know if the SDGs are no more than pious hopes.

\section{Partnering}

The GCR, moreover, is seeking to address an issue that should never have arisen, the failure by the international community as a whole to respond to refugee movements: from the very outset in 1951, the United Nations set out that refugees were owed rights and that protection required international co-operation.

Considering that the United Nations has, on various occasions, manifested its profound concern for refugees and endeavoured to assure refugees the widest possible exercise of these fundamental rights and freedoms,

Considering that the grant of asylum may place unduly heavy burdens on certain countries, and that a satisfactory solution of a problem of which the United Nations has recognized the international scope and nature cannot therefore be achieved without international co-operation, .... (1951 Convention, Preamble, paragraphs 2 and 4)

The preamble is a full part of the treaty and is to be taken into consideration when one is looking to interpret it "in accordance with the ordinary meaning to be given to [its] terms ... in their context and in the light of its object and purpose" (Vienna Convention, art 31.1; Crawford, 381).

Preambular paragraph 4's reference to international co-operation to alleviate the burden of hosting refugees may not be directly referenced in the articles of the 1951 Convention, as was proposed by the Secretary-General in the drafting process (Goodwin-Gill 2016), but ensuring non-refoulement, the core principle of the Convention set out in Article 33.1, requires support to those states hosting large numbers of refugees in protracted situations of displacement; the international principle of fairness, as explained by Franck (Franck 1998), requires co- 
operation from states where a fundamental obligation to protect individuals falls on one a just a few states, a fact recognised in practice in the pledging conferences held in response to humanitarian crises.(3) Given that UNHCR has been given a mandate to provide international protection to refugees by the General Assembly (UNHCR Statute, para 1), states' obligations under Article 1.3 of the Charter back up the GCR commitment for fairer and more predictable burden- and responsibility-sharing (UN Charter).

Furthermore, while the GCR is not legally binding, it references its roots in the protection regimes of international refugee law and international human rights law, both treaty-based and customary. International human rights law is grounded in the three principles or respect, protect, fulfil. In relation to the rights needed by refugees during their displacement, Article 2.1 International Covenant on Economic, Social and Cultural Rights is pertinent, particularly as it provides that states will "take steps, individually and through international assistance and co-operation ... with a view to achieving progressively the full realization of the rights recognized in the present Covenant" (emphasis added - ICESCR).

Unless the GCR establishes a series of inter-state commitments so that there is fairer responsibility- and burden-sharing, it will do no more than reiterate oft-stated avowals of support that do not address either huge humanitarian crises or the protracted refuge that is provided by host states over decades with ever-reducing levels of support from the rest of the international community.(4) As the World Bank has shown, since 1991 the same ten conflicts (Afghanistan, Azerbaijan, Burundi, Colombia, Democratic Republic of Congo, Iraq, Somalia, Sudan, Syria, and the former Yugoslavia) have produced the majority of refugees, so the same neighbouring states are hosting the largest numbers (World Bank 2018, 21-23). A partnership may not be explicitly established in international law with respect to burden- and responsibility-sharing, but there are several separate strands which, when taken together, show that the GCR commitment is more than a pious hope.

Rule of law

A different approach towards facilitating the success of the GCR would, therefore, be to draw on a different UN framework, one that would also promote partnerships within and outside the organization, especially with UNDP and the World Bank. There are many references to international human rights law and human rights instruments in the GCR, but paragraph 9 provides the one reference to rule of law. It is seen as part of the framework for prevention and solutions, although rule of law is pertinent to the entire GCR framework, from protecting refugees in the country of asylum, enhancing the capacity of those countries, facilitating voluntary repatriation to the country of nationality, through to promoting co-operation within the international community and operationalizing interoperability within and beyond the UN as between humanitarian and development actors. Rule of law is a vast topic, even broader when good governance is read with it as is common throughout the UN (UN Rule of Law; Gilbert \& Rüsch 2018; Rudnicka \& Ferris 2018). Rule of law and good governance may not be set out in any single international instrument, but the concepts are understood globally, and member states of the United Nations have agreed that a 'thick' rule of law is one that encompasses good governance and is binding on all international actors (UN SecretaryGeneral 2004; UNHLMGA 2012, para 2; UN General Assembly rule of law resolution 2018, para 18).

2. We recognize that the rule of law applies to all States equally, and to international organizations, including the United Nations and its principal organs, and that respect for and promotion of the rule of law and justice should guide all of their activities and accord predictability and legitimacy to their actions. We also recognize that all 
persons, institutions and entities, public and private, including the State itself, are accountable to just, fair and equitable laws and are entitled without any discrimination to equal protection of the law. (emphasis added)

Rule of law operates at both the domestic and international levels, where there is, in addition, a discrete understanding in relation to its application to international organizations. At the international level, rule of law draws on both the Anglo-American and Continental European (Rechtsstaat) models. As Loughlin makes clear, the Anglo-American approach has been refined through the courts and, in many ways, it is about judicial control of the other branches of government so that the law governs all actors within the State (Loughlin 2010, 315-17; Krygier 2015, 781-83; Dicey \& Wade 1959). The danger is that it leads to a very judicialized understanding, one that is slightly at odds with the UN's framework, where courts are generally less in evidence at the international level. On the other hand, the classic understanding of Rechtsstaat would not suffice as a framework for the UN on its own (Palombella 2010, 11).

Originally, Rechtsstaat only existed where the State itself was the source of law. The idea that law might be separate from the State was inconceivable. The Rechtsstaat means that law is the structure of the State, not an external limitation to it. Its voice is rationality and strict legality of administrative action, the supremacy of which over ordinary citizens was granted despite the recognition of rights and the autonomy of individuals. Liberty is a consequence not truly a premise of the law.

After Nazism, which proclaimed that it governed through laws, post-1945 Rechtsstaat embedded constitutional guarantees to protect the individual from an authoritarian State/sovereign (Krygier 2015, 783; Palombella 2010, 25-26, 31). Having regard to modern Rechtsstaat and l'Etat de droit, one can conceive a broader remit that is more suited to implementing rule of law at the international level, particularly as regards the UN and both its external and internalized adoption of the principle. The German principle of Rechtsstaat focuses more on the regulation of the State through a constitutional order 'as a machine that would go of itself' (Loughlin 2010, 336; Kammen 1987). While the judiciary plays a role, the idea of modern Rechtsstaat is one where the relevant principles, discussed below, direct the State or, in this case, an international organization, so as to create a constitutional structure that fosters support from those affected by its exercise of power - this represents a better framework for rule of law in the context of the UN's humanitarian operations. Alongside the Anglo-American understanding that sees rule of law as an independent constraint on actions by parties, the two approaches to rule of law taken together provide a better framework for applying the rule of law in the context of the UN's humanitarian and development operations. For certain, elements of rule of law developed under the Anglo-American approach need to be applied in UN operations, but the conceptual framework of Rechtsstaat, where it shapes the very conduct of the state/ international organization with respect to those over whom it provides a governance structure, better reflects how UN operations function. It is even more useful in relation to displaced populations across borders and under different UN country mandates but the same concept of rule of law (Gilbert \& Rüsch 2018, 33-35, 37-39). While rule of law may not have been the explicit underpinning theory during the drafting phase, its usefulness in rolling out the GCR in acute and protracted refugee crises at the domestic and international levels cannot be underestimated, as is set out below.

Rule of law in all its different manifestations reflects a compact by members of the relevant society as to how that society shall be governed. As regards the international community, international rule of law helps to establish justice and equity between states: as the UN Charter makes clear, all states are equal (Article 2.1), but Article 1.4 sets out that the United 
Nations is to be "a centre for harmonizing the actions of nations in the attainment of these common ends", including:

Article 1.3: To achieve international cooperation in solving international problems of an economic, social, cultural, or humanitarian character, and in promoting and encouraging respect for human rights and for fundamental freedoms for all without distinction as to race, sex, language, or religion. (emphasis added)

Thus, the GCR in operationalizing a framework for international co-operation through "voluntary but mutually reinforcing and dedicated contributions", reflects the rule of law commitments already assumed and undertaken by all states in relation to their own dealings as between themselves: therefore, while there are existing treaty obligations that support the objective of enhancing protection and assistance for refugees and host communities, the rule of law as adopted by the General Assembly in 2012 underpins the need for states and the wider international community to implement international co-operation under the Charter and in line with the GCR's commitment for fairer and more predictable burden- and responsibility-sharing (UNHLMGA 2012, para 2).

Within the UN, though, there is more than one approach by its different agencies to applying rule of law principles, sometimes focusing on policing, justice and corrections (5), whereas in other contexts it embraces a 'thick' interpretation that encompasses international human rights standards, good governance and resilience, all of which are intrinsic to the proper functioning and implementation of the GCR (SR TJR 2012, paras 12-13)(6). As such, rule of law facilitates three aspects of the GCR as highlighted throughout the Formal Consultations: scope of commitments; state obligations; and interoperability with UN and other partners.

At its most minimal, rule of law simply establishes whether something qualifies as law, but even in this regard it has something to add to the GCR. The GCR makes reference to international refugee law, international human rights law and international humanitarian law and the obligations they impose on states, particularly those hosting refugee populations. The GCR, however, also refers, as stated, to the SDGs, and to the Sendai Framework, and other documents that reflect various degrees of obligation (GCR para 9, fnn 8 and 32)(7).

Referencing rule of law at the outset of the GCR in the context of its ultimate objective, solutions to displacement, provides the means for states to operationalise the GCR, itself nonbinding, and the range of international instruments to which it refers, in a way that upholds the legally binding commitments set out in the 1951 Convention and 1967 Protocol, for instance, alongside those other equally non-binding documents that, like the GCR, build on extant but underdeveloped norms, such as the principle of international co-operation (UN Charter, Art 1.3).

Rule of law may not, as stated, be defined in any single instrument, but it is applicable without ratification by states. As such, it provides a framework for application of the standards in the GCR across all refugee operations. Those states parties to international refugee law and international human rights law instruments, as part of meeting rule of law at the domestic level, should implement those obligations for everyone on their territory and subject to their jurisdiction. Where states are not party to such instruments, then nondiscrimination is a fundamental principle of rule of law that means, when read with the SDGs, that those displaced should not be left behind as the state implements Agenda 2030. This has especial relevance for empowering all displaced persons, particularly women and the girl-child, and obtaining access to education, health care and justice. The SDGs already incorporate displaced persons, but the rule of law framework complements and supports those commitments (SDG 16.9, para 45, Bullet 3, and para 70). 
The final area where a thick interpretation of the rule of law supports the GCR as well as the omnibus General Assembly resolution on UNHCR is in regard to how it facilitates the operationalization of interoperability within and beyond the United Nations (UN Omnibus Resolution 2018; Gilbert \& Rüsch 2018, 49-58). Reference has already been made to good governance and resilience with respect to UNDP and the World Bank, which tends to use good governance in ways that other actors use rule of law, but since 2004, UN actors have adopted rule of law frameworks for operations into which UNHCR could programme humanitarian and development activities for the protection of refugees, either directly or through country of asylum capacity building (UN Secretary-General 2004; UNHLMGA 2012). The GCR requires, by its very nature, that UNHCR, in exercising its unique mandate for the international protection of refugees and seeking permanent solutions for them by assisting governments, operates alongside partners (UNHCR Statute, paras 1 and 8a; GCR, paras 23, 32, 35 and 36; UN Omnibus Resolution 2018, paras 19-22, 34-41, 44-45 and 76).

76. The generosity and solidarity of host countries and the communities that welcome refugees across the globe must be matched by more timely and predictable support, in line with the spirit of burden- and responsibility-sharing. The proposed global refugee compact presents an historic opportunity and sets in motion an irreversible path to achieve this. It has the potential to mobilize support for a shared agenda, grounded in the fundamental principles of humanity and solidarity, which could bring real change to the lives of refugees and the countries and communities that receive them. It represents a concrete, workable instrument of multilateralism in action, rooted in practical engagement to advance refugee protection and solutions. To work, it requires resources, strong leadership and — above all - a firm commitment to the principles and actions that have been so carefully put forward by States and key partners over the past year.

The focus on voluntary repatriation in the GCR, will require capacity building in the country of nationality, along with development actors facilitating its restoration (GCR, paras 87-89; Gilbert 2018, Voluntary Repatriation). During the displacement, similar considerations arise with respect to the country of asylum. As such, rule of law is a framework for operationalizing the goals set out in the GCR and the partnerships it envisages between states, between states and international organizations and as between those international organizations inter se (UNDP 2018). It also enhances the ability of the UN to Deliver as One because it is a framework for the whole organization, both its humanitarian and development wings. Finally, the interaction of the GCR with the Global Compact on Safe Orderly and Regular Migration (GCM) could equally be promoted given the International Organization for Migration's use of rule of law, too.

In sum, the GCR sets out that it is not legally binding - as such, the reference to 'commitments', at first blush, seems unsupported. What needs to be incorporated into the GCR, therefore, is a framework to stop it becoming a set of pious hopes that still leave lowand middle-income countries bearing an unfair and inequitable burden in relation to the 85 per cent of refugees whom they are hosting within their borders. Rule of law, adopted by the international community as a whole in 2012 , provides one method to address the conundrum of commitments in this context:

- commitments as between states;

- commitments by the international community as a whole, especially UNHCR, to the country of asylum;

- commitments, again by the international community as a whole to facilitate conditions in the source state to allow refugees to return in safety and dignity; 
- and, finally, commitments as between humanitarian and development actors to ensure no individual or state is left behind.

\section{INDICATORS}

While the GCR is not binding, there is a commitment to establish indicators by which to assess how far it is being operationalized: indicators for compliance, therefore, could be understood as a practical and necessary consequence of establishing commitments within a non-binding document (GCR, paras 7, 48, 102 and 103).

102. Success under the global compact will be assessed in terms of progress towards the achievement of its four objectives (para 7). Indicators in this regard will be developed for each objective ahead of the first Global Refugee Forum in 2019. Paragraph 7 provides as follows:

7. The objectives of the global compact as a whole are to: (i) ease pressures on host countries; (ii) enhance refugee self-reliance; (iii) expand access to third country solutions; and (iv) support conditions in countries of origin for return in safety and dignity. The global compact will seek to achieve these four interlinked and interdependent objectives through the mobilization of political will, a broadened base of support, and arrangements that facilitate more equitable, sustained and predictable contributions among States and other relevant stakeholders.

As Paragraph 5 has made clear, the GCR "emanates from fundamental principles of humanity and international solidarity, and seeks to operationalize the principles of burden-and responsibility-sharing to better protect and assist refugees and support host countries and communities" (emphasis added). Thus, in interpreting the four objectives in Paragraph 7, regard must be had to the fundamental principles of the GCR of enhanced protection and assistance and fairer and more predictable burden- and responsibility-sharing.

Indicators vis-à-vis refugee protection and assistance and the situation of host communities may be related to existing international human rights law standards. Thus, at one level a range of indicators already exists against which to measure compliance and implementation: for instance, is the right to education being met, and can refugees exercise the right to work? While the GCR is non-binding, it cannot be wholly divorced from a series of pre-existing international obligations by which States are bound. That said, however, not all States are parties to all the relevant treaties, and even where they are, the rights may be restricted more than one would want in terms of providing better protection and assistance to refugees (8).

Even though there are pre-existing rights relating to protection, this does not mean that the indicators will be easy to draft or that they will lead to the enhancement of those rights (OHCHR 2012, 21). The experience with the Millennium Development Goals reveals that there is no guaranteed improvement in rights simply because there are indicators (FukudaParr et al.). While the development of the SDGs learnt from and built on this experience (9), indicators necessarily make states focus on statistics, not necessarily on protection for the sake of protection (Diaz-Martinez-\& Gibbons). Furthermore, there is no necessary correlation between the statistics that are collected regarding achievement of the indicators and respect for, protection of, and fulfilment of rights. As Williams and Hunt have made clear, the data relating to the SDG indicators do not correlate to all elements of specific rights and there may not be sufficient disaggregation (Williams \& Hunt, 11-17; Davis). Thus, even with protection and assistance, indicators will need to be devised specific to the GCR and its objectives. The creation of indicators of the sort proposed during the Formal Consultations on the GCR cannot simply draw on existing models because each context is unique. Indicators will only 
have value if designed to measure the operationalization of the specific commitments established by the GCR.

When it comes to indicators for more predictable and equitable burden- and responsibilitysharing, although there may be a much more limited legal framework underpinning it, that does not mean that a rights-based approach cannot be applied, especially since paragraph 5 of the GCR refers expressly to international human rights law. The fundamental principle of burden- and responsibility-sharing is set out in extant treaty obligations (UN Charter Art. 1.3; 1951 Convention, Preamble para 4). And as regards some aspects of burden- and responsibility-sharing, there is clearly a direct correlation with international human rights law. For instance, article 2(1) of the ICESCR calls on states to undertake 'through international assistance and co-operation, especially economic and technical' to fully realize the rights in that treaty, some of which directly pertain to the GCR. While that provision provides little detail to assist in formulating indicators, it does uphold the idea that a rightsbased approach should be part of the process for establishing indicators for burden- and responsibility-sharing.

That said, the indicators for burden- and responsibility-sharing are as much about obligations between States as they are about protecting refugees and host communities, and finding durable and sustainable solutions to respond to displacement. The lack of a precise, preexisting legal framework makes the establishment of detailed indicators, underpinned by robust statistics, even more important - and this may take time to develop. Relevant datasets may not exist, and even where data has been gathered for different purposes, it may not be directly applicable - for example, the number of refugees may not have been disaggregated (Green, 1085; Williams \& Hunt; Davis). The speed at which events change during displacement adds yet another layer of complexity to data collection and analysis. And, ultimately, in measuring burden- and responsibility-sharing there is an element of comparing chalk and cheese: how much of a contribution does a state make when taking in 100,000 refugees, as against a State that contributes US $\$ 40$ million to aid budgets (and does it matter if it is humanitarian or development aid?), or one that permanently resettles 1500 refugees, or even contributes a thousand troops to a peacekeeping mission for six months? And can one subtract from contributions, however measured and valued, the amount a State makes from the sales of arms and armaments that fuelled the conflict that has caused the refugee flow (to paraphrase UNHCR)? Establishing indicators is essential, but it will take time and experience to ensure that they properly reflect the complex reality of refugee protection and ensure that the commitments of the GCR are being fulfilled (Gilbert 2019).

\section{THE (FALSE) HUMANITARIAN-DEVELOPMENT DICHOTOMY}

Although not directly ensuring that the GCR commitments will be fulfilled, one aspect of its approach to protracted humanitarian crises implicitly builds on frameworks that are underpinned by fairer and more predictable burden- and responsibility-sharing (Gilbert \& Rüsch, 53-54). The modal average length of a protracted refugee situation is around twenty years (Devictor and Do). During that period, priorities will inevitably change and the humanitarian crisis that prompted flight will become a situation of protracted displacement. The refugees will then need to be seen as part of the development plans for the state of refuge as it continues to uphold the fundamental guarantee of non-refoulement. As Paragraph 1 of the GCR explains: "[millions] of refugees live in protracted situations, often in low- and middle-income countries facing their own economic and development challenges, and the average length of stay has continued to grow". 
The GCR makes frequent reference to the need for humanitarian and development agencies to work together from the outset of the displacement (10). Failure to address the practical reality of situations of protracted displacement in the past led to the creation of a parallel 'state' on the territory of the country of asylum that trapped the refugees and had no benefit for the hosting government of the local population (GCR, para 66; Cartagena +30; Goldston, 22; UN Dep. Secretary-General; UNHCR-OECD, para 2; ILO R205; Jordan Compact 2016). If refugees are 'warehoused' in remote camps, the broader range of rights to which they are entitled under international refugee law and international human rights law can be ignored. Recognizing that the majority of refugees are now in urban settings and therefore need to be integrated whilst protected in the country of asylum, the necessary consequence is that they should be part of its national development plans. In line with the SDGs, Paragraph 1 of the GCR goes on to provide that "refugees and host communities should not be left behind" given that the SDGs make no specific reference to refugees, it has to be assumed that they are included in the state's general commitments in relation to Agenda 2030, especially having regard to the references found in the UN General Assembly Resolution adopting the SDGs (SDG Resolution, paras 23 and 29). Thus, refugees are at once under both the humanitarian and development 'umbrellas' of the United Nations and broader international community. The World Bank, UNDP and ICRC, for example, are contributors to enhanced protection and assistance of refugees and fairer and more equitable burden- and responsibility-sharing by the international community as a whole, as well as being part of improved interoperability in the humanitarian and developments sectors.

As the World Bank's research makes clear, if the same conflicts have given rise to most of the displacement over almost thirty years, the same neighbouring countries will have been most affected and the refugee numbers should be part of the state's planning processes. In that regard, the World Bank has made available loans on extremely favourable terms to lowincome countries in order to respond to forced displacement (World Bank 2018, 21-23). Through the International Development Association (IDA), the World Bank has made an additional US\$2 billion to respond to refugees and host communities (11). Nevertheless, like all development initiatives, it is based on loans, unlike humanitarian assistance - given that refugees are not nationals of the state, the additional development financing places an extra burden on host countries as a consequence of offering protection to refugees. The GCR expressly provides, therefore, that development assistance should not affect humanitarian assistance.

65. Without affecting humanitarian assistance, development actors will work in a complementary manner to humanitarian assistance interventions to ensure that the impact of a large refugee situation on a host country is taken into account in the planning and implementation of development programmes and policies with direct benefits for both host communities and refugees. A spirit of partnership, the primacy of country leadership and ownership, and the mobilization of predictable international responses consistent with national development strategies and aligned with the 2030 Agenda for Sustainable Development, are key to ensuring sustainability. At the same time, host countries need to be able to rely on additional development resources to ensure that communities affected by a refugee situation are not impaired in making progress towards the Sustainable Development Goals.

It is a difficult balance to maintain, but the increased role of development actors goes towards ensuring that the commitments of the GCR are operationalized, although it will take careful planning to ensure it does not covertly add a new burden to hosting states. 
In terms of fulfilling the GCR's objectives as set out in Paragraph 7, finding durable and sustainable solutions to the forced displacement, enhancing refugee protection and assistance during situations of displacement, and ensuring fairer responses to burden- and responsibility-sharing, are all part of a broad understanding of "[operationalisation] through voluntary contributions to achieve collective outcomes" (Paragraph 4). Unlike the 1951 Convention, the GCR is as interested in the source state and the burden on the country of asylum, as well as the protection of the refugees. Paragraphs 85-100 are dedicated to the traditional solutions of voluntary repatriation, resettlement and local integration, along with complementary pathways for admission to third countries. While Paragraphs 90-93 recognize that resettlement is "a tangible mechanism for burden- and responsibility-sharing and a demonstration of solidarity, allowing States to help share each other's burdens and reduce the impact of large refugee situations on host countries", it is also acknowledged that previously it has only been offered by a few countries - it should also be noted that only about 102000 refugees were resettled in 2017, a very small dent in the 23 million refugees of concern to UNHCR (UNHCR Population Statistics). Thus, in many ways Paragraphs 85-100 emphasise the limitations of the GCR as a non-binding document: while it deals with voluntary repatriation and with promoting the conditions for return in the country of origin, it is, as ever, consensual, and no commitment to any set increase in resettlement numbers could be obtained from the international community as a whole as part of the GCR (Gilbert 2018, Voluntary Repatriation).

Nevertheless, there is one element of the GCR that does promote solutions and enhances the degree of commitment thereto.

103. The Global Refugee Forums [paras 17-19] will provide an important vehicle for States and other relevant stakeholders to take stock of progress towards the achievement of the objectives of the global compact. Forums will also provide an opportunity for States and relevant stakeholders to exchange good practices and experiences, both with respect to specific country or regional situations, as well as on a global level, and to review the ongoing efficacy of the arrangements for burden- and responsibility-sharing. The stocktaking at the Forums will be informed by the results of the process coordinated by UNHCR to measure the impact arising from hosting, protecting and assisting refugees (para 48), and a mechanism for tracking implementation of pledges and contributions, as well as measuring the impact of the global compact, established by UNHCR in close consultation with States and other relevant stakeholders.

The follow-up mechanism proposed hardly establishes an enforceable set of obligations on states participating in the Global Refugee Forum, but, as stated at the outset, states rarely use judicial or quasi-judicial mechanisms even where they do exist: the diplomatic engagements through the Forum as it responds to current statistics and reports on how states in the global north have shared the burdens and responsibilities of low- and middle-income states that host 85 per cent of the world's refugees may well achieve improvements in promoting solutions, especially resettlement. For lawyers, it may not seem like a means to uphold the GCR's socalled commitments, but the continued engagement in periodic Global Refugee Forums and High Level Officials' Meetings represents a massive improvement over the current regime where protracted refugee crises are forgotten in the wake of new displacement and the funding to countries hosting large refugee populations dries up year by year. International human rights law, as it developed from the Universal Declaration of Human Rights 1948 (UDHR 1948), established treaty monitoring and reporting mechanisms for states parties. While it is possible to read similar obligations into Article 35 of the 1951 Convention, that has not been the practice so far and is unlikely to be adopted now. Even if it were, it would 
not address all the aspects of refugee protection in protracted crises that the GCR recognises as essential to promote justice for all those affected by displacement in protracted humanitarian crises. The regular GRFs and HLOMs at which enhanced protection and assistance and fairer and more predictable burden- and responsibility-sharing will be on the agenda are another mechanism through which to ensure commitments are met without the GCR being legally binding.

\section{CONCLUSION}

The GCR represents a radical new departure in the protection of refugees, especially in recognizing the cost to States that host large numbers. Like any new departure, the practical implications of operationalizing a non-binding document - which nevertheless reflects states' political commitment to provide concrete contributions to burden- and responsibility-sharing by the international community as a whole - will take time to resolve. However, various factors suggest that while it is non-binding, the commitments are more than mere pious hopes. First, the United Nations provides a variety of frameworks that call on states to honour those commitments, not least of which is rule of law: accepted by all states and expressly declared to apply to the UN as well, rule of law enhances the protection and assistance owed to refugees and establishes a means by which to operationalise the principle of international co-operation on which fairer and more predictable burden- and responsibility-sharing is based (Gilbert \& Rüsch, 63). Equally, indicators are an essential step in ensuring proper burdenand responsibility-sharing through international cooperation, and they will be essential in making the Global Refugee Forums effective in monitoring the operationalization of the GCR and in promoting future improvement. The GCR is dependent on the operationalization of interoperability between humanitarian and development actors in order to assist all states in meeting their commitments - in that regard, too, rule of law provides a useful intra-agency mechanism for co-operation, as well as enhancing state capacity and leadership (Gilbert \& Rüsch, §4).

For certain, the GCR is not a legally binding treaty with some supranational treaty body of independent experts capable of holding states to account and where states acknowledge its authority and comply with its decisions. What it does is set out the perilous situation in which the international community finds itself as regards protracted forced displacement across borders, it acknowledges the current unfair distribution of burdens and responsibilities with respect to hosting refugee populations, it devises means by which the international community as a whole can better respond to displacement crises, and it provides mechanisms through which the operationalization of the GCR can be monitored and the principle of international co-operation promoted. And nor does it exist in a vacuum and there are several instances where it is underpinned by binding rules of international law on which UNHCR can draw to monitor its operationalization and oversee how states uphold the commitments it enshrines.

\section{References}

\section{UN Documents}

1951 Convention - 189 UNTS 137; see also, the 1967 Protocol, 606 UNTS 267.

CRRF - Comprehensive Refugee Response Framework, UNGA res 71/1, Annex 1 (19

September 2016).

Deputy Secretary-General Jan Eliasson, 'UN Deputy Chief Calls for Greater Integration

Efforts to Meet Challenges of Refugees in Urban Areas'

$<$ http://www.un.org/apps/news/story.asp?NewsIDS971\#.V8fenmXns7M>.

GCR - Global Compact on Refugees, UNGA res 73/151, Part II (17 December 2018). 
GCM - Global Compact on Safe Orderly and Regular Migration (GCM), UNGA res 73/195, 19 December 2018.

ICESCR - International Covenant on Economic, Social and Cultural Rights (1966), 993 UNTS 3.

ILO R205 - International Labour Organization Recommendation 205

Jordan Compact 'Jordan Compact 2016'

<data.unhcr.org/syrianrefugees/download.php?id=12008>.

New York Declaration - New York Declaration on Refugees and Migrants, UNGA res 71/1 (19 September 2016).

OHCHR 2012 - UN OHCHR, 'Human Rights Indicators: A Guide to Measurement and Implementation' (2012), UN Doc. HR/PUB/12/5, 21.

SDG Resolution - UNGA res 70/1 (25 September 2015).

SDGs - Sustainable Development Goals 2015, 'Transforming our World: The 2030 Agenda for Sustainable Development', UNGA res 70/1 (25 September 2015).

Sendai - Sendai Framework for Disaster Risk Reduction 2015-2030, UNGA res 69/283 (3 June 2015).

SR TJR 2012 - Report of the Special Rapporteur on the promotion of truth, justice, reparation, and guarantees of non-recurrence to the General Assembly, UN doc A/67/368 (13 September 2012).

UDHR 1948 - Universal Declaration of Human Rights 1948, UNGA res 217A (III).

UN Charter - Charter of the United Nations 1945, 892 UNTS 119.

UN General Assembly rule of law resolution 2018 - UNGA res 73/207 (20 December 2018).

UN Omnibus Resolution 2018 - UN General Assembly Resolution on the Office of the

United Nations High Commissioner for Refugees, UNGA res 73/151 (17 December 2018).

UN Rule of Law - <https://www.un.org/ruleoflaw/thematic-areas/governance/good-

governance/>.

UN Secretary-General 2004 - Report of the Secretary-General, S/2004/616 (23 August 2004).

UN Secretary-General 2017 - Secretary-General's Triple Nexus of Humanitarian-

Development-Peace that is encapsulated in the 2017 New Way of Working, OCHA

https://www.unocha.org/sites/unocha/files/NWOW\%20Booklet\%20low\%20res.002_0.pdf.

UNDP 2018 - Written Submission by UNDP to Draft 1 of the GCR, 21 March 2018, pp.2, 4

and 6 - <https://www.unhcr.org/uk/events/conferences/5aba3ee77/undps-written-submissionfirst-draft-global-compact-refugees.html $>$.

UNGA Press Release 2018 - UNGA Press Release, 17 December 2018,

https://www.un.org/press/en/2018/ga12107.doc.htm.

UNHCR Population Statistics - UNHCR Population Statistics

http://popstats.unhcr.org/en/resettlement

UNHCR Statute - Statute of the Office of UNHCR, UNGA res 428 (V) (14 December 1950).

UNHCR-OECD Memorandum of Understanding (15 June 2016).

UNHCR, Figures at a Glance - UNHCR, Figures at a Glance,

https://www.unhcr.org/uk/figures-at-a-glance.html.

UNHLMGA 2012 - UN High Level Meeting of the General Assembly UNGA res 67/1 (24

September 2012); see also, Key Documents at <www.un.org/ruleoflaw/keydocuments>.

Vienna Convention - Vienna Convention on the Law of Treaties, 1155 UNTS 331.

Other documents

Allott 2016 - Philip Allott, Eutopia, (Edward Elgar, 2016).

Boyle \& Chinking 2007 - Alan Boyle \& Christine Chinkin, The Making of International Law (OUP, 2007). 
Cartagena +30 - Cartagena +30 , 'Brazil Declaration and Plan of Action: A Framework for Cooperation and Regional Solidarity to Strengthen the International Protection of Refugees, Displaced and Stateless Persons in Latin America and the Caribbean', (Brasilia, 3 December 2014) <www.refworld.org/docid/5487065b4.html >

Cassese 1981 - Antonio Cassese, 'The Status of Rebels under the 1977 Geneva Protocol on Non-International Armed Conflicts', 30 International \& Comparative Law Quarterly 416 (1981).

Crawford, 2012 - James Crawford, Brownlie's Principles of Public International Law, Davis - SLM Davis, 'The uncounted: politics of data and visibility in global health', 21 The International Journal of Human Rights 1144 (2017).

Devictor \& Do - Xavier Devictor and Quy-Toan Do, 'How many years do refugees stay in exile?', World Bank, 15 September 2016 <http://blogs.worldbank.org/dev4peace/how-manyyears-do-refugees-stay-exile>.

Diaz-Martinez \& Gibbons - E. Díaz-Martínez and ED Gibbons, 'The Questionable Power of the Millennium Development Goal to Reduce Child Mortality', 15 Journal of Human Development and Capabilities: A Multi-Disciplinary Journal for People-Centered Development 203 (2014).

Dicey \& Wade 1959 - Albert V Dicey and Emlyn CS Wade, Introduction to the Study of the Law of the Constitution (10th edn, Oxford University Press, 1959).

Franck 1998 - Thomas M. Franck, Fairness in International Law and Institutions (OUP, 1998).

Fukuda-Parr - S. Fukuda-Parr, AE Yamin and J. Greenstein, 'The Power of Numbers: A Critical Review of Millennium Development Goal Targets for Human Development and Human Rights', 15 Journal of Human Development and Capabilities: A Multi-Disciplinary Journal for People-Centered Development, 105 (2014).

Gammeltoft-Hansen 2019 - Thomas Gammeltoft-Hansen, 'The Normative Impact of the Global Compact on Refugees', 30 International Journal of Refugee Law 605-10 (2019). Gilbert \& Rüsch - Geoff Gilbert and Anna Magdalena Rüsch, 'Rule of Law and United Nations Interoperability', 30 International Journal of Refugee Law 31 (2018).

Gilbert 1997 - Geoff Gilbert, 'The Best 'Early Warning' is Prevention: Refugee Flows and European Responses', 9 International Journal of Refugee Law 207 (1997).

Gilbert 2011 - Geoff Gilbert, 'Law and human rights rather than international human rights law', in Geoff Gilbert, Françoise Hampson and Clara Sandoval, Strategic Visions for Human Rights, 19-33 (Routledge, 2011).

Gilbert 2018, Voluntary Repatriation - Geoff Gilbert, Written Contribution to the Formal Consultations, The International Law of Voluntary Repatriation, 19 April 2018 $<$ https://www.unhcr.org/uk/events/conferences/5ae079557/comment-draft-1-gcrinternational-law-voluntary-repatriation.html $>$.

Gilbert 2019 - Geoff Gilbert, 'Indicators for the Global Compact on Refugees', 30

International Journal of Refugee Law 635 (2019).

Goldston - James Goldston, 'New Rules for the Rule of Law' in David Marshall (ed), The International Rule of Law Movement: A Crisis of Legitimacy and the Way Forward (Harvard University Press, 2014) 19

Goodwin-Gill 2016 - Guy S Goodwin-Gill, 'The movements of people between states in the 21st century: an agenda for urgent institutional change', 28 International Journal of Refugee Law 679 (2016).

Green - M. Green, 'What we talk about when we talk about Indicators: Current Approaches to Human Rights Measurement' 23 Human Rights Quarterly 1084 at 1085 (2001). Higgins 1994 - Rosalyn Higgins, Problems and Process: International Law and How We Use It, 3 (Clarendon Press, 1994). 
ICRC Blogpost 2018 - G. Carbonnier, 'Revisiting the nexus: Numbers, principles and the issue of social change', ICRC BlogPost, 4 October 2018, http://blogs.icrc.org/law-andpolicy/2018/10/04/revisiting-nexu...ebc66b-57ead84e979072701\&mc_cid=57ead84e97\&mc_eid=195aac4589.

ICVA 2018 - ICVA briefing paper, Navigating the Nexus, https://reliefweb.int/sites/reliefweb.int/files/resources/ICVA_Nexus_briefing_paper\%20\%28 Low\%20Res\%29.pdf.

Kammen 1987 - Michael Kammen, A Machine that Would Go of Itself: The Constitution in American Culture (Alfred A. Knopf, 1987).

Koskenniemi 2018 - Martii Koskenniemi, 'What is International Law For?', in Malcolm Evans, International Law, (OUP (5 ${ }^{\text {th }}$ ed), 2018).

Krygier 2015 - Martin Krygier, 'Rule of Law (and Rechtsstaat)' in James D Wright (ed), International Encyclopaedia of the Social and Behavioural Sciences (Elsevier, 2nd edn, vol 20, 2015).

Loughlin 2010 - Martin Loughlin, 'Rechtsstaat, Rule of Law, l'Etat de droit', in Martin Loughlin, Foundations of Public Law (OUP, 2010).

Murray 2014 - Daragh Murray, 'How International Humanitarian Law Treaties Bind NonState Armed Groups', 20 Journal of Conflict \& Security Law 101 (2015).

Palombella 2010 - Gianluigi Palombella, 'The Rule of Law as an Institutional Ideal' in Leonardo Morlino and Gianluigi Palombella (eds), Rule of Law and Democracy (Brill, 2010). Roberts \& Sivakumaran 2012 - Anthea Roberts \& Sandesh Sivakumaran, 'Lawmaking by Nonstate Actors: Engaging Armed Groups in the Creation of International Humanitarian Law', 37 Yale Journal of International Law 108 (2012).

Rudnicka \& Ferris 2018 - Paula Rudnicka and Elizabeth Ferris, 'When People Flee: Rule of Law and Forced Migration', ABA Rule of Law Initiative (April 2018), available at $<$ https://www.americanbar.org/content/dam/aba/images/rule_of_law/maestro-images/abaroli-issue-paper-when-people-flee-rule-of-law-and-forced-migration-0418.pdf > .

Sivakumaran 2006 - Sandesh Sivakumaran, 'Binding Armed Opposition Groups' 55 International \& Comparative Law Quarterly 369 (2006).

Williams \& Hunt - C. Williams and P. Hunt, 'Neglecting human rights: accountability, data and Sustainable Development Goal 3', 21 The International Journal of Human Rights 1 (2017).

World Bank 2018 - World Bank, Forcibly Displaced www.worldbank.org/forciblydisplaced. 
(1) Some of the following ideas are developed from the author's Written Contribution to the Formal Consultations on the GCR, 'Squaring the Circle - A Non-Binding Document with Commitments' - see <https://www.unhcr.org/uk/events/conferences/5abb95cb7/regarding-draft-1squaring-circle-non-binding-document-commitments.html>. And see, Geoff Gilbert, 'Indicators for the Global Compact on Refugees', 30 International Journal of Refugee Law, 635-39 (2019).

(2) There are very few inter-state cases before international human rights treaty bodies, none at all under Art 41 International Covenant on Civil and Political Rights, 999 UNTS 171, and no cases under Art 381951 Convention before the ICJ.

(3) See the High Level Pledging event for Yemen, 26 February 2019 <https://www.unocha.org/yemen/2019-high-level-pledging-event>.

(4) See World Food Programme on ever increasing demands that current donations do not satisfy (http://www1.wfp.org); see also, UNHCR re DRC emergency:

Despite the enormous needs, UNHCR has received less than a quarter of the

US\$236.2 million required to provide life-saving assistance and protection to refugees, IDPs and other vulnerable people in the DRC.

<http://www.unhcr.org/uk/dr-congo-emergency.html>. See also, 'UNHCR and partners seek US\$296 million for Burundi refugee crisis', available at <https://www.unhcr.org/news/briefing/2019/1/5c3d9cdd4/unhcr-partners-seek-us296million-burundi-refugee-

crisis.html?utm_source=NEWS\&utm_medium $=$ email\&utm_content $=1 \mathrm{st}+$ section +2 nd +story+unhcr\&utm_campaign=HQ_EN_therefugeebrief_external_20190115>.

(5) See

http://www.undp.org/content/undp/en/home/ourwork/crisispreventionandrecovery/foc us_areas/rule-of-law/global-focal-point-for-police--justice-and-corrections-/.

(6) On UNDP and resilience, see

http://www.undp.org/content/undp/en/home/librarypage/climate-and-disaster-

resilience-/resilient.html. On the World Bank, see

<http://www.worldbank.org/en/country/switzerland/publication/building-resilienceworld-bank-group-experience-in-climate-and-dsaster-

rsilient?cid=EXT_WBEmailShare_EXT $>$.

(7) ILO Resolution, 'Employment and Decent Work for Peace and Resilience

Recommendation', 2017 (No. 205),

<https://www.ilo.org/dyn/normlex/en/f?p=NORMLEXPUB:12100:0::NO::P12100_I

LO_CODE:R205>, adopted by the General Conference of the International Labour

Organization and the "Guiding principles on the access of refugees and other forcibly displaced persons to the labour market" (ILO, July 2016).

(8) Article 13.2(a) International Covenant on Economic, Social and Cultural Rights, 993 UNTS 3 only guarantees free primary education to all - free secondary education and beyond is part of what states are progressively trying to fulfil. See also, Article 28 UN Convention on the Rights of the Child, UNGA res. 44/25, annex, 44 UNGAOR Supp. (No. 49) at 167, U.N. Doc. A/44/49 (1989).

(9) The SDGs were agreed in 2015, but the indicators were only finalised in July 2017 UNGA res 71/313, 6 July 2017.

(10) GCR, paras 3, 8, 9, 23, 26-27, 32, 35-36, 64-65, 70, 79, 88-89 - and that ignores all the references to developing capacity within states.

(11) During the 2017-18 secondment to UNHCR, the World Bank made a presentation as part of the Formal Consultations on how the IDA18 Sub-Window 
would provide additional monies to low-income countries hosting refugee numbers greater than 25,000 or $0.1 \%$ of population in the form of a 38 -year loan at $0 \%$ interest and with six years of grace. See also,

$<$ http://www.worldbank.org/en/topic/fragilityconflictviolence/brief/forceddisplacement $>$. 